\title{
EFFECT OF MOTOR ABILITY AND SELF-CONFIDENCE ON TRIPLE JUMP SKILLS IN YOUTH AGED 18-20: PATH ANALYSIS STUDY AMONG STUDENTS AT UNIVERSITY COLLEGE
}

\author{
Herli Pardilla ${ }^{1}$, Achmad Sofyan Hanif ${ }^{1}$, Hidayat Humaid ${ }^{1}$, Firmansyah Dlis ${ }^{1}$, \\ Raffly Henjilito ${ }^{2}$, Jufrianis ${ }^{3}$ \\ ${ }^{1}$ Post-graduate Program in Sport Education, State University Of Jakarta (UNJ) \\ ${ }^{2}$ Physical Education Department, Islamic University Of Riau (UIR) \\ ${ }^{3}$ Physical Education Department, Pahlawan University (UP)
}

Corresponding Author: Herli Pardilla, e-mail: herlipardilla_por15s3@mahasiswa.unj.ac.id Accepted for Publication: June 20, 2019

Published: June 25, 2019

DOI:10.17309/tmfv.2019.2.03

\begin{abstract}
The purpose of the study is to analyze the impact of motor skills and self-confidence on triple jump skills. Materials and methods. The study participants $(n=41)$ were male college students aged 18-20 years. Regression analysis (path analysis) was used to analyze the interrelationship between motor skills variable variables, self-confidence (exogenous variables) and triple jump skills (endogenous variables).

Results. The analysis indicated that there is an influence of motor skills towards triple jump skills with $=$ $(r \geq 0.711 ; p<0.000$; significant $)$ and a linear determination coefficient $\left(R^{2} \geq 0.506\right)$ contributing $50.60 \%$ There is an influence of self-confidence on triple jump skills with $=(r \geq 0.707, p<0.000$; significant $)$ and a linear determination coefficient $\left(R^{2} \geq 0.50\right)$ contributing $50.00 \%$. There is an influence of motor skills on self-confidence with $=(r \geq 0.693, p<0.000$; significant $)$ and a linear determination coefficient $\left(R^{2} \geq 0.480\right)$ contributing $48.00 \%$. There is an influence of motor skills and self-confidence on triple jump skills with $=$ $(r \geq 0.771, p<0.000$; significant $)$ and a linear determination coefficient $\left(\mathrm{R}^{2} \geq 0.594 ; p<0.005\right.$; significant $)$, the total exogenous variable contribution is $59.40 \%$.

Conclusions. Motor skills and self-confidence must be considered by educators or trainers during the training process. Good motor skills and high self-confidence will affect triple jump skills.

Keywords: triple jump skills, motor ability, self-confidence.
\end{abstract}

\section{Introduction}

Triple jump is defined as a series of runs, jumps with quick movements from a predetermined jump or support that are two times the same foot hop and one other leg with a simultaneous movement (Djumidar, 2004). Athletic transmissible jump has basic technique elements consisting of approach, hop, step, and jump (Panoutsakopoulos \& Kollias, 2008). The triple jump is a complex movement consisting of three separate phases, combined with a single movement in an effort to maximize the farthest distance (Wilson, Simpson, \& Hamill, 2009). This jump consists of three stages: take-off hop, step, and jump (Mohammed, Idris, Ali, \& Nasreddin, 2016).

(C) Herli Pardilla, Achmad Sofyan Hanif, Hidayat Humaid, Firmansyah Dlis, Raffly Henjilito, Jufrianis, 2019.
Physical activity in sports really requires skills in its practice to be able to give the best performance. The acquisition of motor skills is fundamental for human life (Zhu, Poolton \& Masters, 2012). Motor refers to movement, bio shows the biological nature (body) of ability (Bompa \& Buzzichelli, 2014). This form can be grouped as: speed, strength, endurance, agility and fatigue (Jerábek, 2003). Motor competence has been defined as the skill level in various motor tasks and coordination of movements and controls that underlie the results of certain movements (Cattuzzo et al., 2014). Movement speed is one of the components of complex motor abilities (Horička, Hianik \& Šimonek, 2014), the triple jump relies heavily on speed in its basic technical abilities. The best jump depends on the run-up. The purpose of the run-up is to make athletes reach the optimum position for landing at a controlled speed in that jump technique (Emel Çetin \& Özgür Özdemir, 
2013), so that the distance of the track to jump determines the result of the jump in the triple jump (Lmuzaini \& Leck, 2008).

Psychological aspects of self-confidence are a supporting factor in mastering the basic techniques of jumps. Confidence is a belief that you have strength in yourself, especially ability, to achieve success (Brewer, 2009). High self-competence and good self-confidence can reduce worries in oneself and will give positive feelings in doing the activities (Badami, Vaezmousavi, Wulf, Vegas, \& Namazizadeh, 2012). Confidence is an important element to be able to create strength in yourself (Dureja \& Singh, 2011). Triple jump has a basic technique that is of very high complexity, so one must have strong self-confidence so as not to hesitate in doing hop, step and jump techniques. To gain sports achievements, psychology must make the increase of athletic self-confidence the most fundamental thing. The analysis of scientific literature revealed the need for further research on motor skills and self-confidence.

\section{Materials and methods}

\section{Study participants}

The study participants were youth aged $18-20$ years $(\mathrm{n}=41)$.

\section{Research organization}

The analysis technique used in this research were literature analysis, test and measurement, and methods of mathematical statistics.

\section{Testing procedure}

Triple jump skill. Distance jump in meters (m) was used. Further, the motor ability test had the following 7 test items: Standing Broad Jump Jumping Test (Strength, explosive leg power), Standing Triple Jump Jumping Test (Strength, explosive leg power), Overhead Back Throw Throwing Test (Strength, Coordination), Sit and Reach (Flexibility), Sprint 30 m Running Test (Stength and Speed), Sprint $150 \mathrm{~m}$ Running Test (Strength, Speed and Endurance), Shuttle Run Running Test (Speed and Agility).
Then the self-confidence questionnaire test statement was compiled using a questionnaire with a Likert scale model.

\section{Statistical analysis}

The analysis technique used in testing the hypothesis of this research was path analysis. The path analysis model was used to analyze the pattern of relationships between variables in order to determine the direct or indirect effects of a set of exogenous variables (motor ablity and self-confidence) towards endogenous variables (triple jump skills). The path testing used Rsquare regression with a significance level (sig 0.05). The spss version 23 application was used for statistical analysis.

\section{Results}

Hypothesis Model: motor ability and self-confidence contributes simultaneously towards triple jump skills.

$$
\begin{array}{r}
\text { Structure Model : TJS }=p_{\text {TJSMA }} \mathrm{MA}+p_{\text {TJSSC }} \\
\mathrm{SC}+p_{Y} \varepsilon_{1}
\end{array}
$$

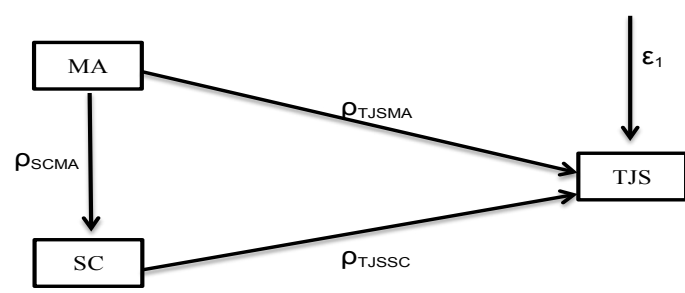

Fig. 1. Path constellation analysis of multiple jump skills

The principle of testing is significant: The SPSS version 23.0 program is indicated by Model Summaryb.

In Table 1, Model Summary ${ }^{\mathrm{b}}$, above, $\mathrm{R}_{\text {square }}=0.594$ was obtained and in the Anova Table, we obtained $\mathrm{F}$ value of 27.811 with a probability value $(\mathrm{sig})=0.000$ because the value of sig is $<0.05$, then the decision is $\mathrm{Ha}$ accepted. Therefore, motor ability and self-confidence contribute simultaneously to triple jump skills.

In Table 2, Anova ${ }^{\mathrm{b}}$, F value of 27.811 was obtained, with probability value $(\mathrm{sig})=0.000$ because the value (sig) is $0.000<0.05$, then the decision is Ho is rejected and $\mathrm{Ha}$ is accepted. Therefore, individual testing can be done.

\begin{tabular}{|c|c|c|c|c|c|c|c|c|c|}
\hline \multirow[b]{2}{*}{ Model } & \multirow[b]{2}{*}{$\mathbf{R}$} & \multirow[b]{2}{*}{ R Square } & \multirow{2}{*}{$\begin{array}{l}\text { Adjusted R } \\
\text { Square }\end{array}$} & \multirow{2}{*}{$\begin{array}{l}\text { Std. Error } \\
\text { of the } \\
\text { Estimate }\end{array}$} & \multicolumn{5}{|c|}{ Change Statistics } \\
\hline & & & & & $\begin{array}{l}\text { R Square } \\
\text { Change }\end{array}$ & F Change & df1 & df2 & $\begin{array}{c}\text { Sig. F } \\
\text { Change }\end{array}$ \\
\hline 1 & $.771^{\mathrm{a}}$ & .594 & .573 & .70346 & .594 & 27.811 & 2 & 38 & .000 \\
\hline \multicolumn{10}{|c|}{ a. Predictors: (Constant), Self-Confidence, Motor Ability } \\
\hline b. Depend & riable: & Jump Skills & & & & & & & \\
\hline
\end{tabular}

Table 1. Model Summary 
According to the individual test shown in the Coefficients Table, the path coefficient result is $p_{\text {TJSMA }}=0.000$.

Table 2. ANOVA $^{\mathrm{a}}$

\begin{tabular}{rlllrrr}
\hline \multicolumn{1}{l}{ Model } & $\begin{array}{c}\text { Sum of } \\
\text { Squares }\end{array}$ & Df & $\begin{array}{c}\text { Mean } \\
\text { Square }\end{array}$ & F & Sig. \\
\hline 1 & Regression & 27.525 & 2 & 13.762 & 27.811 & $.000 \mathrm{~b}$ \\
& Residual & 18.804 & 38 & .495 & & \\
& Total & 46.329 & 40 & & & \\
\hline
\end{tabular}

a. Dependent Variable: Triple Jump Skills

b. Predictors: (Constant), Self-Confidence, Motor Ability

a. Motor ability contributes towards triple jump skills

Table 3. Coefficients ${ }^{\mathrm{a}}$

\begin{tabular}{|c|c|c|c|c|c|c|}
\hline & \multirow[b]{2}{*}{ Model } & \multicolumn{2}{|c|}{$\begin{array}{l}\text { Unstandardized } \\
\text { Coefficients }\end{array}$} & \multirow{2}{*}{$\begin{array}{c}\text { Standardized } \\
\text { Coefficients } \\
\text { Beta } \\
\end{array}$} & \multirow[b]{2}{*}{ t } & \multirow[b]{2}{*}{ Sig. } \\
\hline & & B & $\begin{array}{l}\text { Std. } \\
\text { Error }\end{array}$ & & & \\
\hline \multirow[t]{2}{*}{1} & (Constant) & 3.517 & .825 & & 4.262 & .000 \\
\hline & $\begin{array}{l}\text { Motor } \\
\text { Ability }\end{array}$ & .012 & .002 & .711 & 6.320 & .000 \\
\hline \multicolumn{6}{|c|}{ a. Dependent Variable: Triple Jump Skills } & \\
\hline
\end{tabular}

In Table 3, Coefficients, sig value. 0.000 was obtained. Apparently, the sig. value 0.000 is smaller than the value of a probability of 0.05 or value $0.05>0.000$, then Ha is accepted, meaning that the path analysis coefficient is significant. So motor abilities contribute to triple jump skills.

The following table shows how much influence the motor ability has on triple jump skills:

In Table 4, Model Summary ${ }^{\mathrm{b}}, \mathrm{R}_{\text {square }}=0.506 \times 100=$ $50.60 \%$ was obtained. And in the Anova Table, we obtained value Fchange $=39.949$ with probability value $(\mathrm{sig})=0.000$, because sig value is $0.000<0.05$, then the decision is $\mathrm{Ha}$ is accepted. So motor ability contributes to triple jump skills.

Self-confidence contributes towards triple jump skills

In the Table Coefficients, the individual test shows that the path coefficient result is $p_{\text {TSMA }}=0.000$.

In Table 5, Coefficients, sig. value 0.000 was obtained. Apparently, the value of Sig. 0.000 is smaller
Table 5. Coefficients $\mathrm{s}^{\mathrm{a}}$

\begin{tabular}{|c|c|c|c|c|c|c|}
\hline & \multirow{2}{*}{ Model } & \multicolumn{2}{|c|}{$\begin{array}{l}\text { Unstandardized } \\
\text { Coefficients }\end{array}$} & \multirow{2}{*}{$\begin{array}{c}\begin{array}{c}\text { Standardized } \\
\text { Coefficients }\end{array} \\
\text { Beta }\end{array}$} & \multirow{2}{*}{$\mathbf{t}$} & \multirow{2}{*}{ Sig. } \\
\hline & & B & $\begin{array}{l}\text { Std. } \\
\text { Error }\end{array}$ & & & \\
\hline \multirow[t]{2}{*}{1} & (Constant) & -2.377 & 1.775 & & -1.339 & .188 \\
\hline & $\begin{array}{l}\text { Self- } \\
\text { Confidence }\end{array}$ & .054 & .009 & .707 & 6.241 & .000 \\
\hline
\end{tabular}

a. Dependent Variable: Triple Jump Skills

than probability value of 0.05 or value $0.05>0.000$, then $\mathrm{Ha}$ is accepted meaning that the path analysis coefficient is significant. So self-confidence contributes to triple jump skills.

The following table shows how much influence selfconfidence has on triple jump skills.

In Table 6, Model Summaryb, above, $\mathrm{R}_{\text {square }}=$ $=0.500 \times 100=50.00 \%$ was obtained and in the Anova Table, we obtained values Fchange $=38.947$ with probability (sig) $=0.000$ because the value of sig is $0.000<0.05$, then the decision is that $\mathrm{H} 0$ is rejected and $\mathrm{Ha}$ is accepted. So self-confidence contributes to triple jump skills.

Motor ability contributes towards self-confidence.

According to the individual tests shown in the Coefficients Table, the path coefficient result is $p_{\text {TISMA }}=0.000$.

In Table 7, Coefficients, sig value. 0.000 was obtained. Apparently, the value of sig. 0.000 is smaller than the probability value of 0.05 or the value of $0.05>$ 0.000 , then $\mathrm{Ha}$ is accepted and $\mathrm{Ho}$ is rejected, meaning that the path analysis coefficient is significant. So, motor ability contributes towards self-confidence.

The influence of the motor ability on self-confidence is as follows.

In Table 8, Model Summaryb, above, $\mathrm{R}_{\text {square }}=$ $=0.480 \times 100=48.00 \%$ was obtained and in the Anova Table, we obtained the value of $\mathrm{F}_{\text {change }}=35.996$ with a probability value (sig) $=0.000$ because the value of sig is $0.000<0.05$, then the decision is that $\mathrm{H}_{0}$ is rejected and $\mathrm{H}_{\mathrm{a}}$ is accepted. So motor abilities contribute to self-confidence.

The framework of the empirical causal relationship between MA and SC towards TJS can be made through the structural equation Model as follows:

Table 4. Model Summary

\begin{tabular}{|c|c|c|c|c|c|c|c|c|c|}
\hline \multirow[b]{2}{*}{ Model } & \multirow[b]{2}{*}{$\mathbf{R}$} & \multirow[b]{2}{*}{ R Square } & \multirow{2}{*}{$\begin{array}{l}\text { Adjusted R } \\
\text { Square }\end{array}$} & \multirow{2}{*}{$\begin{array}{c}\text { Std. Error } \\
\text { of the } \\
\text { Estimate }\end{array}$} & \multicolumn{5}{|c|}{ Change Statistics } \\
\hline & & & & & $\begin{array}{l}\text { R Square } \\
\text { Change }\end{array}$ & F Change & df1 & df2 & $\begin{array}{c}\text { Sig. F } \\
\text { Change }\end{array}$ \\
\hline 1 & $.711 \mathrm{a}$ & .506 & .493 & .76605 & .506 & 39.949 & 1 & 39 & .000 \\
\hline
\end{tabular}

a. Predictors: (Constant), Motor Ability

b. Dependent Variable: Triple Jump Skills 
Table 6. Model Summary ${ }^{\mathrm{b}}$

\begin{tabular}{|c|c|c|c|c|c|c|c|c|c|}
\hline \multirow[b]{2}{*}{ Model } & \multirow[b]{2}{*}{$\mathbf{R}$} & \multirow[b]{2}{*}{ R Square } & \multirow[b]{2}{*}{$\begin{array}{l}\text { Adjusted R } \\
\text { Square }\end{array}$} & \multirow{2}{*}{$\begin{array}{l}\text { Std. Error } \\
\text { of the } \\
\text { Estimate }\end{array}$} & \multicolumn{5}{|c|}{ Change Statistics } \\
\hline & & & & & $\begin{array}{c}\text { R Square } \\
\text { Change }\end{array}$ & F Change & df1 & df 2 & $\begin{array}{c}\text { Sig. F } \\
\text { Change }\end{array}$ \\
\hline 1 & $.707 \mathrm{a}$ & .500 & .487 & .77095 & .500 & 38.947 & 1 & 39 & .000 \\
\hline \multicolumn{10}{|c|}{ a. Predictors: (Constant), Self-Confidence } \\
\hline b. Depend & t Variable & le Jump Skills & & & & & & & \\
\hline
\end{tabular}

Table 7. Coefficients ${ }^{\mathrm{a}}$

\begin{tabular}{|c|c|c|c|c|c|c|}
\hline & \multirow{2}{*}{ Model } & \multicolumn{2}{|c|}{$\begin{array}{l}\text { Unstandardized } \\
\text { Coefficients }\end{array}$} & \multirow{2}{*}{$\begin{array}{c}\begin{array}{c}\text { Standardized } \\
\text { Coefficients }\end{array} \\
\text { Beta }\end{array}$} & \multirow{2}{*}{$\mathbf{t}$} & \multirow{2}{*}{ Sig. } \\
\hline & & B & $\begin{array}{l}\text { Std. } \\
\text { Error }\end{array}$ & & & \\
\hline \multirow[t]{2}{*}{1} & (Constant) & 138.506 & 11.049 & & 12.535 & .000 \\
\hline & $\begin{array}{l}\text { Motor } \\
\text { Ability }\end{array}$ & .158 & .026 & .693 & 6.000 & .000 \\
\hline
\end{tabular}

Model Structure:

$\mathrm{TJS}=p_{\mathrm{TJSMA}} \mathrm{MA}+p_{\mathrm{TJSSC}} \mathrm{SC}+p_{\mathrm{TJS}} \varepsilon_{1}=0.000 \mathrm{MA}+$ $+0.000 \mathrm{SC}+0.406 \varepsilon_{1}$

Value of $\mathrm{R}_{\text {TJ.SC.MA }}^{2}$ or $\mathrm{R}_{\text {square }}$ can be seen in Table 1, Model Summary ${ }^{\mathrm{b}}$. The value of $p_{\mathrm{y}} \varepsilon_{1}$ (residual variable) is determined by the formula as follows:

Formulation:

$p_{\mathrm{TJS}} \varepsilon_{1}=1-\mathrm{R}_{\text {square }}=1-0.594=0.406$

\section{Discussion}

Based on the testing result of all the hypotheses that have been done, there is a significant simultaneous effect of motor ability and self-confidence towards triple jump skills. Structural equation from the results of path analysis of leg muscle explosive power and transmissible jump results in triple jump skills $=0.000 \mathrm{MA}+0.000 \mathrm{SC}+0.406 \varepsilon$

The amount of the motor ability contribution and self-confidence variables together to triple jump skills is equal to Rsquare $=0.594 \times 100=59.40 \%$, while the remaining $40.60 \%$ is the influence of other variables apart from the motor ability variable and self-confidence.

The contribution of motor ability variable (MA) to triple jump skills (TJS) is directly the same with $\mathrm{R}_{\text {square }}=$ $=0.506 \times 100=50.60 \%$. It is because of the maximum

Table 8. Model Summary

\begin{tabular}{|c|c|c|c|c|c|c|c|c|c|}
\hline \multirow[b]{2}{*}{ Model } & \multirow[b]{2}{*}{$\mathbf{R}$} & \multirow[b]{2}{*}{ R Square } & \multirow{2}{*}{$\begin{array}{c}\text { Adjusted R } \\
\text { Square }\end{array}$} & \multirow{2}{*}{$\begin{array}{c}\text { Std. Error } \\
\text { of the } \\
\text { Estimate }\end{array}$} & \multicolumn{5}{|c|}{ Change Statistics } \\
\hline & & & & & $\begin{array}{c}\text { R Square } \\
\text { Change }\end{array}$ & F Change & df1 & df2 & $\begin{array}{l}\text { Sig. F } \\
\text { Change }\end{array}$ \\
\hline 1 & $.693 a$ & .480 & .467 & 10.25801 & .480 & 35.996 & 1 & 39 & .000 \\
\hline \multicolumn{10}{|c|}{ a. Predictors: (Constant), Motor Ability } \\
\hline b. Depend & Variabl & -Confidence & & & & & & & \\
\hline
\end{tabular}

strength and speed in the basic technique of the prefix. Strength is a motor ability that greatly determines movement skills (Lukić, Bijelić, Zagorc \& ZuhrićŠebić, 2011). Self-confidence variable (SC) has a direct contribution of $\mathrm{R}_{\text {square }}=0.500 \times 100=50.00 \%$ to triple jump skills. Furthermore, the influence of the motor ability on self-confidence is equal to $\mathrm{R}_{\text {square }}=0.480 \times$ $\times 100=48.00 \%$.

The basic technique of transmissible jumping which has high complexity makes students hesitate in its implementation. Athletes with a high level of doubt in sports activities show a very low confidence (Koivula \& Hassme, 2002). This is based on self-confidence which expresses individual's belief in his/her general ability to control conditions and situations (Besharat \& Pourbohlool, 2011).

This finding shows that to improve triple jump skills, athletes must have good motor skills and selfconfidence, both of which contributing $59.40 \%$ to be able to improve triple jump skills. Thus, there was found a significant effect of motor ability and self-confidence on triple jump skills after testing hypotheses together or testing individually.

\section{Conclusions}

In this research, it has been proved that there is a positive influence of motor ability variables towards triple jump skills, there is a positive effect of selfconfidence on triple jump skills, and there is a positive influence of motor ability towards self-confidence. With the motor ability variable (MA), self-confidence (SC) has a very significant influence on improving triple jump skills (TJS) by $59.40 \%$. While the remaining $40.60 \%$ are the effects of variables outside of the motor ability and self-confidence variables. Educators or trainers must consider the variable of motor abilities and selfconfidence in an effort to develop triple jump skills. 


\section{Conflict of interest}

The author declares no conflict of interests.

\section{References}

Badami, R., Vaezmousavi, M., Wulf, G., Vegas, L., \& Namazizadeh, M. (2012). Feedback About More Accurate Versus Less Accurate Trials: Differential Effects on Self-Confidence and Activation. Research quarterly for exercise and sport, 83(2), 1-8. https://doi. org/10.5641/027013612800745275

Besharat, M. \& Pourbohlool, S. (2011). Moderating Effects of Self-Confidence and Sport Self-Efficacyon the Relationship between Competitive Anxietyand Sport Performance. Psychology, 2, 760-765. doi: 10.4236/ psych.2011.27116

Bompa, T., \& Buzzichelli, C. (2014). Periodization Training for Sports-3rd Edition (hird Editi). United States of America: Human Kinetics. Retrieved from https:// books.google.com/books?id=Zb7GoAEACAAJ\&pgis=1

Brewer, B. W. (2009). Handbook of Sports Medicine and Science (First Publ). Chichester, West Sussex, UK: Blackwell Publishing.

Djumidar. (2004). Gerak-Gerak Dasar Atletik dalam Bermain. Jakarta: PT RajaGrafindo Persada.

Dureja, G., \& Singh, S. (2011). Self-confidence and decision making between psychology and physical education students: A comparative study, 2(6), 62-65.

Emel Çetin, Özgür Özdemir, Y. Ö. (2013). Biomechanical Evaluation of the Phases of the Triple Jump TakeOff in a Top Female Athlete. 5th World Conference on Educational Sciences-WCES Turkey: Akdeniz University, 2747.
Jerábek, P. (2003). The preparation of junior athletes for the combined events. New Studies in Athletics, 18(4), 38.

Horička, P., Hianik, J., \& Šimonek, J. (2014). The relationship between speed factors and agility in sport games. Journal of Human Sport and Exercise, 9(1), 4958. https://doi.org/10.4100/jhse.2014.91.06

Koivula, N., \& Hassme, P. (2002). Self-esteem and perfectionism in elite athletes: effects on competitive anxiety and self-confidence, 32, 866.

Lukić, A., Bijelić, S., Zagorc, M., \& Zuhrić-Šebić, L. (2011). The importance of strength in sport dance performance technique. SportLogia, 7(1), 61-67. https://doi. org/10.5550/sgia.110701.en.061L

Lmuzaini, K. H. S. A., \& Leck, S. T. J. F. (2008). Msljteapap, 22(4), 1265-1272.

Mohammed, Z., Idris, M. M., Ali, B., \& Nasreddin, B. M. (2016). Influence Technique Vs Ideal Model on Credibility Theory Distributions Ratios: a Case Study of Triple Jump Ratios: a Case Study of Triple Jump. European Scientific Journal, 11(20), 334-346.

Panoutsakopoulos, B. V., \& Kollias, I. A. (2008). Essential parameters in female triple jump technique, (4), 53-61.

Cattuzzo, M. T., dos Santos Henrique, R., Ré, A. H. N., de Oliveira, I. S., Melo, B. M., de Sousa Moura, M., ... Stodden, D. (2016). Motor competence and health related physical fitness in youth: A systematic review. Journal of Science and Medicine in Sport, 19(2), 123129. https://doi.org/10.1016/j.jsams.2014.12.004

Wilson, C., Simpson, S., \& Hamill, J. (2009). Movement coordination patterns in triple jump training drills. Journal of Sports Sciences, 27(3), 277-282. https://doi. org/10.1080/02640410802482433

Zhu, F., Poolton, J., \& Masters, R. (2012). Neuroscientific aspects of implicit motor learning in sport. Routledge Handbook of Motor Control and Motor Learning, 155-174.

\title{
ВПЛИВ РУХОВИХ ЗДІБНОСТЕЙ ТА ВПЕВНЕНОСТІ У СОБІ НА ФОРМУВАННЯ НАВИЧОК ПОТРІЙНОГО СТРИБКА У МОЛОДІ 18-20 РОКІВ: ДОСЛІДЖЕННЯ 3 ВИКОРИСТАННЯМ ПАТ-АНАЛІЗУ СЕРЕД СТУДЕНТІВ КОЛЕДЖУ УНІВЕРСИТЕТУ
}

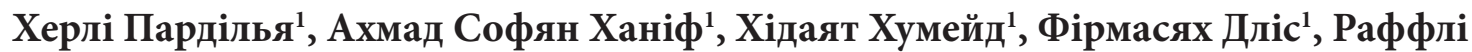 \\ Хеньітіто ${ }^{2}$, Юфріас ${ }^{3}$ \\ ${ }^{1}$ Аспірантура за спеціальністю «Спортивне виховання», Державний університет \\ Джакарти (UNJ) \\ ${ }^{2}$ Кафедра фізичного виховання, Iсламський університет Piay (UIR) \\ ${ }^{3}$ Кафедра фізичного виховання, Університет Пахлаван (UP) \\ Реферат. Стаття: 5 с., 8 табл., 17 джерел.
}

Метою дослідження є аналіз впливу рухових навичок та впевненості у собі на розвиток навичок потрійного стрибка.

Матеріали і методи. Учасниками дослідження ( $\mathrm{n}=41)$ були студенти коледжу чоловічої статі віком 18-20 років.

Регресійний аналіз (пат-аналіз) використовувався для аналізу взаємозв'язку між змінними ру- хових навичок, впевненістю у собі (екзогенні змінні) та навичками потрійного стрибка (ендогенні змінні).

Результати. Аналіз показав, що рухові навички впливають на навички потрійного стрибка $(r \geq 0,711 ; p<0,000$; значення достовірні) та лінійний коефіцієнт детермінації $\left(\mathrm{R}^{2} \geq 0,506\right)$ із внеском $50,60 \%$. Впевненість у собі впливає на навички 
потрійного стрибка ( $r \geq 0,707, p<0,000$; значення достовірні) та лінійний коефіцієнт детермінації $\left(\mathrm{R}^{2} \geq 0,50\right)$ із внеском 50,00\%. Рухові навички впливають на впевненість у собі $(r \geq 0,693, p<0,000$; значення достовірні) та лінійний коефіцієнт детермінації $\left(\mathrm{R}^{2} \geq 0,480\right)$ із внеском 48,00\%. Рухові навички та впевненість у собі впливають на навички потрійного стрибка ( $r \geq 0,771, p<0,000$; значення достовірні) та лінійний коефіцієнт детермінації $\left(\mathrm{R}^{2} \geq 0,594\right.$; $p<0,005$; значення достовірне), загальний внесок екзогенної змінної 59,40 \%.

Висновки. Педагоги або тренери мають враховувати важливість рухових навичок та впевненості у собі під час тренувального процесу. Добре розвинені рухові навички та високий рівень впевненості у собі впливають на розвиток навичок потрійного стрибка.

Ключові слова: навички потрійного стрибка, рухові здібності, впевненість у собі.

\title{
ВЛИЯНИЕ ДВИГАТЕЛЬНЫХ СПОСОБНОСТЕЙ И УВЕРЕННОСТИ В СЕБЕ НА ФОРМИРОВАНИЕ НАВЫКОВ ТРОЙНОГО ПРЫЖКА У МОЛОДЕЖИ 18-20 ЛЕТ: ИССЛЕДОВАНИЕ С ИСПОЛЬЗОВАНИЕМ ПАТ-АНАЛИЗА СРЕДИ СТУДЕНТОВ КОЛЛЕДЖА УНИВЕРСИТЕТА
}

\author{
Херли Пардилья ${ }^{1}$, Ахмад Софян Ханиф${ }^{1}$, Хидаят Хумейд ${ }^{1}$, Фирмас Длис ${ }^{1}$, Раффля \\ Хеньитито $^{2}$ Юфриас ${ }^{3}$ \\ ${ }^{1}$ Аспирантура по специальности «Спортивное воспитание», Государственный \\ университет Джакарты (UNJ) \\ ${ }^{2}$ Кафедра физического воспитания, Исламский институт Риау (UIR) \\ ${ }^{3}$ Кафедра физического воспитания, Университет Пахлаван (UP) \\ Реферат. Статья: 5 с., 8 табл., 17 источников.
}

Целью исследования является анализ влияния двигательных навыков и уверенности в себе на формирование навыков тройного прыжка.

Материалы и методы. Участниками исследования $(\mathrm{n}=41)$ были студенты колледжа мужского пола в возрасте 18-20 лет.

Регрессионный анализ (пат-анализ) использовался для анализа взаимосвязи между переменными двигательных навыков, уверенностью в себе (экзогенные переменные) и навыками тройного прыжка (эндогенные переменные).

Результаты. Анализ показал, что двигательные навыки влияют на навыки тройного прыжка $(r \geq 0,711$; $<<0,000$, значение достоверны) и линейный коэффициент детерминации $\left(\mathrm{R}^{2} \geq 0,506\right)$ с вкладом 50,60\%. Уверенность в себе влияет на навыки тройного прыжка $(r \geq 0,707 ; p<0,000$, значение достоверны) и линейный коэффициент детерминации
$\left(\mathrm{R}^{2} \geq 0,50\right)$ с вкладом 50,00\%. Двигательные навыки влияют на уверенность в себе $(r \geq 0,693$; $p<0,000$, значение достоверны) и линейный коэффициент детерминации $\left(\mathrm{R}^{2} \geq 0,480\right)$ с вкладом 48,00\%. Двигательные навыки и уверенность в себе влияют на навыки тройного прыжка $(r \geq 0,771 ; p<0,000$, значение достоверны) и линейный коэффициент детерминации $\left(\mathrm{R}^{2} \geq 0,594 ; p<0,005\right.$, значение достоверное), общий вклад экзогенной переменной 59,40\%.

Выводы. Педагоги или тренеры должны учитывать важность двигательных навыков и уверенности в себе во время тренировочного процесса. Хорошо развитые двигательные навыки и высокий уровень уверенности в себе влияют на развитие навыков тройного прыжка.

Ключевые слова: навыки тройного прыжка, двигательные способности, уверенность в себе. 


\section{Information about the authors:}

Herli Pardilla: herlipardilla_por15s3@mahasiswa.unj.ac.id; https://orcid.org/0000-0001-6777-3479; Post-graduate Program in Sport Education, State University Of Jakarta (UNJ) Jakarta, Indonesia

Achmad Sofyan Hanif: Sofyanhanif.unj@unj.ac.id; https://orcid.org/0000-0003-1343-8936; Post-graduate Program in Sport Education, State University Of Jakarta (UNJ) Jakarta, Indonesia

Hidayat Humaid: hidayathumaid@ymail.com; https://orcid.org/0000-0001-6479-7520; Post-graduate Program in Sport Education, State University Of Jakarta (UNJ) Jakarta, Indonesia

Firmansyah Dlis: Post-graduate Program in Sport Education, State University Of Jakarta (UNJ) Jakarta, Indonesia

Raffly Henjilito: rafflyhenjilito@edu.uir.ac.id; Physical Education Department, Islamic University Of Riau (UIR) Pekanbaru, Indonesia

Jufrianis: jufrianis93@gmail.com; Physical Education Department, Pahlawan University (UP) Bangkinang, Indonesia

Cite this article as: Herli Pardilla, Achmad Sofyan Hanif, Hidayat Humaid, Firmansyah Dlis, Raffly Henjilito, Jufrianis (2019). Effect Of Motor Ability And Self-Confidence On Triple Jump Skills In Youth Aged 18-20: Path Analysis Study Among Students At University College. Teoriâ ta Metodika Fizičnogo Vihovannâ, 19(2), 69-75. https://doi.org/10.17309/ tmfv.2019.2.03

Received: 16.05 .2019 . Accepted: 20.06.2019. Published: 25.06 .2019

This work is licensed under a Creative Commons Attribution 4.0 International License (http://creativecommons.org/ licenses/by/4.0). 